\title{
The Revenge of the Simulacrum: the Reality Principle Meets Reality TV
}

\author{
Rob Kroes ${ }^{1}$
}

Published online: 22 August 2019

(C) The Author(s) 2019

\begin{abstract}
The central ingredient in the process, widely studied, of Americanization may well be the power of American mass culture to turn everything into spectacle and entertainment. If well over a hundred years ago the appeal of William Cody/Buffalo Bill lay in his power to turn recent real-life events on America's frontier into the mass entertainment offered by his Wild West Show, today we witness the further development where spectacle and entertainment have in fact taken the place of real-life events. No more need of fine distinctions between reality and its entertainment version; spectacle and entertainment are the new reality. America's president now seems simply to continue performing his reality-TV persona, which had already turned him into the simulacrum of an authentic American hero. This paper will analyze current trends and give recent examples where the virtual world of mass entertainment has come to set the parameters for our sense of what is reality and what its fake version. It also analyzes the effects on political life and political traditions.
\end{abstract}

Keywords Anti-semitism · Citizens United v. Federal Election Commission (2010) · Corporate person · Economic marketplace/ political marketplace $\cdot$ Fake reality $\cdot$ Economic/political inequality $\cdot$ Populist movements $\cdot$ Social media $\cdot$ U.S. Supreme Court . White racism

One flourishing field in American Studies has been a form of reception studies, focusing on the ways in which American popular culture developed and turned into an inspiration for national cultures elsewhere, especially in the trans-Atlantic setting. Explanatory frameworks ranged from the cultural agency behind the dissemination of American popular - or "mass" culture - to a focus more on the channels of dissemination, the media used in the process and individuals crucially positioned in networks of dissemination. Yet another explanatory approach focused on "the pleasure principle" as a factor in the reception of forms of American mass culture by self-constituted foreign publics. Studies of this process in a semiotic vein have pointed to the quasi-alchemy involved in the ways in which America has developed a mastery in techniques of spawning its own simulacra, its own pop-cultural pantheon, its cultural bricolage that foreigners can adapt. This may be the central ingredient in the process, widely

\section{Rob Kroes}

Amsterdam, The Netherlands studied, of Americanization. The central explanatory vector here is to do with the power of American mass culture to turn everything into spectacle and entertainment. If well over a hundred years ago the appeal of William Cody/Buffalo Bill lay in his power to turn recent reallife events on America's frontier into the mass entertainment offered by his Wild West Show, today we witness the further development where spectacle and entertainment have in fact taken the place of real-life events. No more need of fine distinctions between reality and its entertainment version; spectacle and entertainment are the new reality. America's president now seems simply to continue performing his reality-TV persona, which made him a public figure.

These developments may have gone beyond a point of no return. The simulacrum may now have reached autonomy and have freed itself from reality checks. This paper will analyze current trends and give recent examples where the virtual world of mass entertainment has now become the source of "memes" posing as snippets of real life. It is a world that threatens to turn us all into avatars of The Apprentice. What is more: politically motivated groups of nationalist and populist inspiration now avail 
themselves of the latest techniques in mass communication to divulge conspiracy views of society and the world, packaged as mass entertainment. ${ }^{1}$ This seemingly endless conversion of reality into virtual reality - its reality-TV version - has a way of turning back on reality. Thus - to give one example - real-life political movements, such as George Soros's manifold endeavors to educate former Soviet satellite states in the ways of democracy under the banner of Karl Popper's ideal of an "open society," have been turned upside down into populist fantasies of Jewish conspiracies of global reach. In this pervert way, the very idea of Popper's "open society" re-enters our real world as the object of populist vengeance and antiSemitic invective. Trends like these will be at the center of my argument, leaving us with the question: has the simulacrum gained the upper hand?

\section{Fake News}

Why not start at the end where everything we write, like words scribbled in the sand, washes away, endlessly, relentlessly? Where nothing will assume stable shape and form, but evanesces before our eyes? Where every gesture is of utter inconsequence, like so much sound and fury signifying nothing? Is this the endgame of our stage of history? If the setting of our world has turned into a projection screen and we are no more than a virtual entity called "the public," we behold shadow figures strutting about, parading before us, and referred to - depending on the channel and the network - either as "Mr. President", or "Individual 1." There are echoes here of T. J. Jackson Lears' No Place of Grace, describing an earlier time, in the late nineteenth century, when everything from the workplace to daily human relations seemed to turn abstract, inspiring a generalized sense of the weightlessness of everything - of, as Milan Kundera would have it, the unbearable lightness of being. It left people in the grip of a then fashionable affliction, as Lears reminds us, known as neurasthenia. In much the same way the spirit of advertising and salesmanship in the later 1920s went about combating status anxieties and the mental panics they caused by inventing another affliction - halitosis - and a simple mouthwash to counter its dismal effects. ${ }^{2}$

General processes of social transformation had ushered in a world changed beyond recognition, unfamiliar, severing timehonored bonds tying people together. No longer were workers meaningfully related to anything they could call the result of

\footnotetext{
${ }^{1}$ Damien Leloup, "Ingérence de l'alt-right américaine en Europe," Le Monde,Sélection hebdomadaire, Samedi, 16 Mars 2019, p.2

2 T.J. Jackson Lears, No Place of Grace: Antimodernism and the Transformation of American Culture, 1880-1920 (Chicago: The University of Chicago Press, 1981)
}

their toil - as young Karl Marx had pointed out in his early work on alienation at the work place - nor, for that matter could capitalist entrepreneurs connect to tangible objects they could call their property. As Berle and Means pointed out in The Modern Corporation and Private Property, following the corporate revolution the bond between ownership and physical property had assumed the abstract form of a share of stock. As the authors put it, physical property in the old sense, capable of being shaped by its owner, represented "an extension of his own personality." With the corporate revolution, this quality has been lost to the property owner much as it has been lost to the worker through the industrial revolution, leaving a widespread sense of alienation in its wake. ${ }^{3}$

What in our present predicament can help us ground ourselves again and reconnect to anything we might call the real world? What can break the spell of this latter-day Wizard of $\mathrm{Oz}$ - and of course we may remind ourselves of Donald Trump here - whose magic wand turns everything into its own fake version, at whose pleasure reality is ordained as if by a Master of Ceremonies in a reality-TV show? How can we begin to see through its chimeras and see the true movers and shakers guiding them? What are the forces of motion giving sense and direction in this highly abstract power play? And a power play it is, aiming for dominion over the marketplace of ideas, or at least what ranks as such in our age of disembodied voices, of computer-generated and algorithm-driven trolling and meme warfare ${ }^{4}$ corrupting and perverting the formation of what used to be known as "public opinion" and "public space," now altered beyond recognition, and turned into its own fake version. How are we to recognize the guiding hands in this process? Whose interests are being served if not those of the democratic public?

We may see this current state of democratic subversion as the outcome of a long-term emergence of a new category of player in the polity. The cherished character of the individual citizen, a real life-and-blood person, had to accommodate the advent of a rival player, the corporate person. As a legal and political fiction, a disembodied voice claiming equal rights on the political agora, it has found its place in legal thought and political theory. ${ }^{5}$ The corporate person now finds itself on a par with the real, or natural, person, and speaks on behalf of the corporate world and its interests.

\footnotetext{
${ }^{3}$ Adolf A. Berle and Gardiner C. Means, The Modern Corporation and Private Property (1932) Book I, ch. IV, 64 (New York: The MacMillan Company 1932)

${ }^{4}$ Trolling has been described as the social media equivalent of "guerrilla warfare" and, importantly for Instagram, "memes are its currency of propaganda." (https://www.theguardian.com/commentisfree/2018/dec/18/theguardian-view-on-instagrams-troll-farms-meme-warfare)

5 I can't help being reminded of a hilarious passage in William S. Burroughs' Naked Lunch about a man who had taught his asshole to talk. At one point, "the asshole would eat its way through his pants and start talking on the street... shouting out it wanted equal rights." W.S. Burroughs, The Naked Lunch (Paris: Olympia Press, 1959)
} 
In fact, what we are living through now may already be a decadent late stage in a development that began to hit the late nineteenth-century world with full force. New forms of ownership, of power and control, had been gestating for well over two centuries, pioneered by Dutch and British merchants in early forms of joint-stock corporate ownership of their trading empires. Now, combined with new forms of industrial production, communication and distribution, the world of corporate ownership could fully come into its own. Among many other things it occasioned new metaphors for describing the forces that made society tick, from Adam Smith's "invisible hand" on to Karl Marx's intriguing pair of concepts of "forces of production" and "relations of production." Human agency as an explanatory concept made way for a view that gave central place to anonymous, collective forces, such as the market.

Early reflections of this paradigm shift can be traced in legal discourse. The individual human being as the central actor in webs of social connections and interactions, from the early nineteenth century on and particularly in American legal thought, had made way for a companion figure. The distinction then arose between "natural persons" and "legal - or corporate - persons." Although nothing like a real person, but rather its metaphorical spin-off, corporate persons were basically fictions. Fictitious or not, though, corporate persons were far from unreal. It has taken over a century of Supreme Court decisions and legal scholarship to clarify such basic questions as to whether corporations had legal rights and interests under the Constitution, as if they were real people and entitled to the same legal protections. Yet, until well into the 1970s, the Supreme Court has generally refused to extend to corporations a Constitutional right that is by its nature applicable only to natural persons or their acts. Under this general principle, First Amendment rights (crucially including the freedom of expression) may not be asserted by corporations because corporations are incapable of expression. The only exception made here is the case of corporations whose shareholders and representatives share a community of views and have banded together precisely to promote these views. Only then can their corporate self be seen to speak in one voice, as in several civil rights cases from the history of the NAACP. The answer should be different, it was long held, for large corporations whose shareholders and representatives have no such community of outlook and opinion to guide their corporate actions.

In 1963 Supreme Court Justice Byron White, in connection with recent Civil Rights cases, again stressed the point that shareholders in business corporations "do not share a common set of political or social views, and they certainly have not invested their money for the purpose of advancing political or social causes." He further argued that "there is no basis whatsoever for concluding that these views are expressive of the heterogeneous beliefs of their shareholders." Yet, lo and behold, a mere half century later the Supreme Court would explode these subtle distinctions in its infamous 2010 decision in Citizens United v. Federal Election Commission (2010). The majority opinion, written by Justice Anthony M. Kennedy, held that the First Amendment protects the right to free speech, even if the speaker is a corporation, and effectively removed limitations on corporate funding of independent political broadcasts. ${ }^{6}$ Since then hundreds of millions of dollars have been poured into funding the organized expression of highly partisan political views, through super PACs - Political Action Committees, allowing a relatively small group of wealthy individuals and corporations to exert an outsize influence on local, state and federal elections. According to a report in 2014 by the Brennan Center for Justice, of the $\$ 1$ billion spent in federal elections by super PACs since 2010 , nearly $60 \%$ came from just 195 individuals and their spouses. ${ }^{7}$

In Citizens United, the Court pointedly overturned a 1990 ruling, Austin v. Michigan Chamber of Commerce. In doing so, the Court explicitly rejected the finding in Austin that regulation of corporate political spending is justified as a legitimate means of remedying the inequity that grows out of the fact that: "state-created advantages not only allow corporations to play a dominant role in the Nation's economy, but also permit them to use 'resources amassed in the economic marketplace' to obtain 'an unfair advantage in the political marketplace'." Doing away with such intellectual sophistication, when the Court saw the nation's economy and the political marketplace as critically connected, the 5-4 majority made itself the enabler of corrosive processes of economic and political inequality. For the moment this may be the temporary terminus of a long period of reflection on the rise of the corporate person and its disembodied voice as a new force in the polity.

\section{In What Voice Does the Corporate Person Speak?}

It had taken legal minds a while before finding language to help them put into words this new phenomenon of the

\footnotetext{
${ }^{6}$ Adam Winkler, We the Corporations: How American Businesses Won Their Civil Rights. (New York: W.W. Norton, 2018)

George F. Canfield, "Is a Large Corporation an Illegal Combination or Monopoly under the Sherman Anti-Trust Act?" Columbia Law Review, Vol.9, No. 2 (Feb., 1909) pp. 95-115 [https://www.jstor.org/stable/1109221] Accessed: 11-12-2018

Charles O'Kelley, "The Constitutional Rights of Corporations Revisited: Social and Political Expression and the Corporation after First National Bank V. Bellotti,” 67 GEO.L.J. 1347 (1979) http://digitalcommons.law. seattleu.edu/faculty/657

${ }^{7}$ Thomas B. Edsall, "After Citizens United, a Vicious Cycle of Corruption: Unconstrained outside spending is corrosive to our democracy," New York Times (https://www.nytimes.com/2018/12/06/opinion/citizens-unitedcorruption-pacs.html; accessed January 31, 2019)
} 
corporate person. A recurring metaphor in the early writing is that of a veil hiding the intricate formation of corporate interests from public scrutiny. ${ }^{8}$ Other contemporary or even earlier observers of a more skeptical mind were less awed. What they saw happening behind the veil was the banding together of groups of people in defense of their common interests, while conspiring to obstruct others in the defense of their conflicting interests. There was a word for that at the time: unlawful combination. And of course it was never the collective defense of a group's own interests that was deemed unlawful, but always that of one's rivals and opponents. Adam Smith, the dispassionate observer of the early stages of the industrial revolution, wrote in The Wealth of Nations (1776): "Whoever imagines that masters rarely combine (i.e. conspire) is as ignorant of this world as of the subject." ${ }^{, 9} \mathrm{He}$ had a keen eye for the ways in which corporate groups "combined" in defense of their interests in the face of the rising threat of organized labor, and more often than not successfully resorted to the courts seeking damages and injunctions against strikes. ${ }^{10}$

Over a century later, when the industrial revolution had firmly taken root across the Atlantic world, the caustic wit of Thorstein Veblen scathingly exposed the life style of the leisure class of his day, in a book that would establish his reputation as a social critic. ${ }^{11}$ In other writings, more strictly focused on the changing economy and its hierarchies of power and leadership, he had this to report from behind the corporate veil: "The arts of business are arts of bargaining, effrontery, salesmanship, make-believe, and are directed to the gain of the business man at the cost of the community, at large and in detail." "But the work in hand in business traffic is not tangible performance. The realities of the business world are money-values; that is to say matters of make-believe which

\footnotetext{
${ }^{8}$ Hugh Evander Willis, "Corporations and the United States Constitution," (1934) Articles by Maurer Faculty. Paper 1253 http://www.repository.law. indiana.edu/facpub/1253 It contains a reference to the use of "the corporate veil" dating back to 1809 . The paper offers a good survey of how economic life in nineteenth century America came under the sway of the corporation and of how legal thought responded to the change.

9 "We rarely hear, it has been said, of the combinations of masters, though frequently of those of workmen. But whoever imagines, upon this account, that masters rarely combine, is as ignorant of the world as of the subject. Masters are always and everywhere in a sort of tacit, but constant and uniform combination, not to raise the wages of labour above their actual rate. To violate this combination is everywhere a most unpopular action, and a sort of reproach to a master among his neighbours and equals. We seldom, indeed, hear of this combination, because it is the usual, and one may say, the natural state of things, which nobody ever hears of." Adam Smith, An Inquiry into the Nature and Causes of the Wealth of Nations (1776), Book I, Chapter 8, "Of the Wages of Labour."

${ }^{10}$ Paul A. Bishop, "The Rise of Unions and Labor Activism," https://www. hccfl.edu/media/161891/unions.pdf This paper discusses the corporate response to the rise of organized labor, including the role of the courts as an anti-organized labor force. On this, see also: Foster Rhea Dulles, Labor in America: A History (New York: Thomas Y. Crowell Company, 1966)

${ }^{11}$ Thorstein Veblen, The Theory of the Leisure Class: An Economic Study of Institutions [1899]. Introduction by Stuart Chase. (New York: The Modern Library, 1934).
}

have the sanction of law and custom and are upheld by the police in case of need." As Veblen saw it, "a new order of businesslike management went progressively into action, and shuffled a new type of persons into the positions of responsibility; men with an eye more single to the main chance at the cost of any whom it may concern." 12 And as if endowed with uncanny powers of foresight, Veblen added: "And all the while the illusions of nationalism allowed the underlying population to believe that the common good was bound up with the business advantage of these captains of solvency" (a characteristic Veblenian sneer), "into whose service the national establishment was gradually drawn, more and more unreservedly, until it has become an axiomatic rule that all the powers of government and diplomacy must work together for the benefit of the business interests of the larger sort ." This is vintage Veblen, unmasking the hallowed leaders of business as essentially preying on the strengths of the economy, as a parasitic element, while hiding behind the veil of corporate respectability, like so many wizards of $\mathrm{Oz}$.

Veblen's Absentee Ownership and Business Enterprise in Recent Times, his last published book (1923), nicely captures the tone and spirit of his views of an America as it entered its era of unhampered corporate profiteering, of glitter and graft. It is this era that would capture Europe's intrigued gaze and spur the European imagination to fill America as a fantasy realm with what Europeans had gathered from film, newspapers, advertising, music and dance crazes. One result was the fascinating blend of Weimar cultural decadence, Chicago gangland romanticism, ${ }^{13}$ and more general American settings, such as in Kurt Weill and Bertolt Brecht's creative collaborations in Rise and Fall of the City of Mahagonny. The narrative ingredients were all European but projected on to an imaginary American screen. Something in the unfettered temerity with which America had entered this new stage of history must have led European creative minds to play their own games while projecting their fantasies onto the larger canvass of an imaginary America. One play in particular, which Brecht wrote in 1941, but which was first performed only in 1958, has gained a peculiar resonance to our ears in the years of the Trump presidency: The Resistible Rise of Arturo Ui. It chronicles the ascent of a fictional 1930s Chicago mobster, who tries to control the cauliflower racket by ruthlessly disposing of the opposition. The play is a satirical allegory of the rise of Adolf Hitler and the Nazi Party in Germany. Yet to us, the evocation of graft, cold vindictiveness, moral turpitude and

\footnotetext{
$\overline{12}$ Thorstein Veblen, Absentee Ownership and Business Enterprise in Recent Times: The Case of America (New York: The Viking Press, Inc., 1923), 107-8, $110,111,114$.

${ }^{13}$ This is the point to remind the reader of one of Chicago's true intellectual treasures, oral historian Studs Terkel, who once described his hometown as theatrically corrupt. Compared to other centers of corruption, Chicago, in his words, is "not more corrupt than other cities, except we're the Big Daddy of it, you see, we're more theatrical in our corruptions." (http://movies2.nytimes. com/books/99/09/26/specials/terkel-interviewing.html)
} 
the ruthless and willful disregard of institutional separations between private interests and public morality, conjure up the traits of the man who now presides over the affairs of state from the White House.

How resistible, to use Brecht's apt word, has this man's rise been? For one thing not that many observers saw it coming. Here was a totally unconventional candidate whose main claim to fame was, well, ... fame. The avenue along which he had come was more like a studio setting, a winding staircase making for the grand descent of the lead character, the Master of Ceremonies of a reality-TV show, Sorcerer to his Apprentices. His entry onto the political stage undeniably was in that grand manner, although lacking the resonance of America's civil religion, of America's masters of oratory and public speech. This time no echoes of Walt Whitman's Chants Democratic, but rather its bleak opposite: Chants Undemocratic, sounding like "lock her up." This is the descent that Trump's theater staircase shows up for our view, the undemocratic vistas that his every public act reveals.

\section{Trump as the Ultimate Simulacrum}

Watching Trump do his thing, signing executive orders in the Oval Office, insulting journalists, trampling under foot every convention and rule of democratic life, all the while acting presidential, one can never resist the impression of the man simulating, play-acting, simply continuing what he must have liked best in his previous life of a mass-media celebrity. He is still the master of his own show (rather than playing second fiddle to the likes of General McMaster and other "adults in the room"), playing the ultimate autocrat firing people at will, in an aura of omnipotence that is the central magnetic appeal to his core constituency - his "base." He really comes to us through the mirror, stepping through the looking glass of our TV sets, as if in an inverse version of Alice in Wonderland, turning everything into fiction and fantasy. In that sense Trump has the free range of action of a veritable simulacrum. In the eyes of his believers he can represent any element of their dreams. He is a poor person's dream of a rich person, as Fran Lebowitz once sardonically put it. ${ }^{14}$ In his self-styled, public persona, he is the successful, self-made American businessman, past master of the art of the deal, in business and now in politics and diplomacy as well, all at the same time, leaving his followers awestruck. He is the ultimate voluntarist in politics, willing things to happen (like bringing dying industries back to life), willing other things to shrivel by simply turning his scornful Gorgon's gaze on them. No checks and balances are needed to contain this man, this ultimate trickster and con artist. Able to subvert reality, calling everything fake

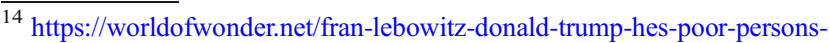
idea-rich-person/
}

that differs from the way the man has willed it, does he have no reality principle to fear that will ever strike back?

For one thing, calling things fake as is Trump's wont reminds us of the old logical conundrum of the Cretan calling all Cretans liars. Who is the outside arbiter to judge? This may put us in mind of The Image, Daniel Boorstin's classic analysis of the infant stage of a rising mass media culture in the United States. ${ }^{15}$ Boorstin shrewdly saw the insatiable appetite for entertainment, whetted by television's commercial use, result in the production of what he called a "pseudo"-reality, more exciting than the regular news. Thus, in that vein, television began to report news items after first turning them into pseudo-events, more exhilarating than any real event. Boorstin's were the warning shots in a critique of mass communication that later would give us Neil Postman's Amusing Ourselves to Death, a study of the intellectual degeneration of the reporting, discussion and commentary of current events and serious matter on TV. ${ }^{16}$ That is precisely the world that gave us Donald Trump as a mass entertainer and perverter of public culture.

Surely Trump has had his meetings with reality, going bankrupt and having to be rescued several times over. It never harmed his image so far, his image of a man always coming out on top. It may now in fact seem as if at long last the simulacrum has stepped out into the real world and taken over our views and perspectives, while turning everything into the matter of mass entertainment. And while the audience is amusing itself to death, behind the veil of our every-day life in our shared "pseudo-reality," the collective corporate interests are keeping their eyes on the ball. This is the world of real corporate interests, of "dark money" flowing from corporate interests to political allies, all working to subvert political agendas and social policies, as well as the established political institutions - Congress, political parties, government, the press - whose traditional role it had always been seen as serving the common weal and making for an informed democratic public.

Trump plays a dual role in all this. Working closely with the moneyed interests that are out to demolish a political agenda in support of income redistribution, environmental protection, public health care, education, he at the same time is busy blinding his own followers to the pursuit of their real interests. He keeps serving them, though, stilling their appetites for entertainment. And it may well be the part of the job that he likes best. Whenever he wants to recharge his batteries, he doesn't do a Scrooge and count his money, but goes back into campaign mode, immersing himself in the cheering crowds. In French one would say that he takes a bain de foule, and Oh,

\footnotetext{
${ }^{15}$ Daniel I. Boorstin, The Image: A guide to Pseudo-Events in America (New York: Harper, Vintage Books, 1962)

${ }^{16}$ Neil Postman, Amusing Ourselves to Death: Public Discourse in the Age of Show Business (New York: Viking/ Penguin, 1985)
} 
how I would love to translate that as "ship of fools," not just for the assonance of the words, but much rather because it would put us in mind of Herman Melville's trickster character, the Confidence Man.

The American novelist Dave Eggers has reported on Trump's campaign in Florida, on his way to the presidency. $\mathrm{He}$ is a shrewd observer, with a cynic's eye for the world of Trumpian illusionism. Having described the awed exhilaration among the crowd awaiting Trump's arrival on board his own jet plane, with the iconic lettering spelling out Trump's name on the plane's body, he goes into Trump's address to the crowd of supporters. And I quote: "Words get lost. His supporters do not care. Nothing in Trump's platform matters. There is no policy that matters. There is no promise that matters. There is no villain, no scapegoat, that matters. If, tomorrow, he said that Canadians, not Mexicans, were rapists and drug dealers, and the wall should be built on that border, no one would blink. His poll numbers would not waver. Because there are no positions and no statements that matter to them. There is only the man, the name, the brand, the personality they have seen on television." ${ }^{17}$ Here are many elements that are akin to cargo cults, originating in the wake of drops of cargo for American troops during the war in the Pacific. Like a latter-day version of manna falling from heaven, orchestrated by a mythical "big man," here were Trump's true believers gathering on an airstrip in Florida, awaiting Trumpian largesse.

This leaves us with the question raised at the beginning of my argument. Are we now in a world where the simulacrum has become totally disjointed from reality checks, where reality can be ignored and overruled? In a world of corporate fictions serving the interests of the happy few, while numbing the minds of the many and blinding them to the view of the real interests that they collectively share? Time, most likely, is of the essence here. We may collectively need patience to see Trumpian fictions exposed as such, to see for instance his paleo-mercantilist view of trade among nations exposed as a spanner in the works of world commerce rather than the cure for making "America great again," and to see the real balance or power in the world reassert itself rather than being willfully ignored. That would take the continuing quest for transparency, as heroically pursued in contemporary journalism, or through the working of the democratic machinery, creaky as it may seem at the moment, to shine a disabusing light on the hocus-pocus of a mass-produced fake reality. It can be done and has been done, as in the days of the Cold War in the work of the intrepid American journalist I.F. Stone. If there is a lesson still to be learned from his tireless endeavor, it is that the news he gathered and distributed through his one-man newsletter - I. F. Stone's Weekly - was all available in print in the public realm, in newspapers, in government documents

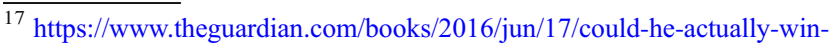
dave-eggers-donald-trump-rally-presidential-campaign
}

and the like, but in need of being salvaged from the daily wash of official, if not "fake," readings of reality. ${ }^{18}$

The challenge today is basically the same. If my story so far has been that of the rise of the corporate body and the disembodied voice, and of how the two go together in uncanny ventriloquism, we must break the spell and unveil the guiding interests even if they are hiding in plain sight. If the final question is of who and what is winning - Trump's web of fictions and fake realities - or a reality principle steadily undermining Trump's pseudo-presidency, we may find heart in all the investigative effort now going into the exposure of what makes Trump's world tick.

\section{Our "Inordinate Fear" of the Disembodied Voice}

During an international digital conference in Tel Aviv, in December 2018, one participant, the ex-Mossad head Tamar Pardo, addressed the issue of Russian digital interference in America's 2016 presidential election. He mentioned the Russians' use of bots in support of their chosen candidate, Donald Trump. ${ }^{19}$ Many experts at the conference spoke of the dangers posed by bots, computer programs designed to run automatically and mimic the cyber behavior of a real user. Pardo said that "what we've seen so far with respect to bots and the distortion of information is just the tip of the iceberg. It is the greatest threat of recent years, and it threatens the basic values that we share - democracy and the world order created since World War Two." The large-scale use of bots, adding their fake voices to the chorus of democratic debate, may already have crucially affected the outcome of elections on both sides of the Atlantic.

Nor is this the only threat to public space and democratic exchange posed by the ways in which the Internet has morphed. Little is left of the utopian anticipations of the early generations of cybernauts, seeing a new global space opening up, transcending local settings and the constraints they brought. ${ }^{20}$ There is widespread awareness today that our every

\footnotetext{
${ }^{18}$ A worthy present-day version of Stone's crusade is Bellingcat, a website launched in 2014 by Eliot Higgins. The site produces regular, and spectacular, journalistic scoops using open-source intelligence. (https://foreignpolicy.com/ gt-essay/taking-on-the-kremlin-from-his-couch-eliot-higgins-bellingcatrussia/)

${ }^{19}$ https://www.haaretz.com/us-news/.premium-ex-mossad-chief-russia-rantrump-for-president-1.6782359

${ }^{20}$ And - full disclosure - I was among those who shared in these utopian dreams and wrote about them. See my "Citizenship in Cyberspace," in Rob Kroes, Them and Us: Questions of Citizenship in a Globalizing World. (Urbana and Chicago: University of Illinois Press, 2000) Chapter 11. The early enthusiasts had a point. I remember one participant in an international seminar, held in Salzburg, Austria, in the early 2000s, a young woman from Jordan. She evoked for us the thrill she felt, each time she sat at her desktop, engaging in conversation with like-minded people across the globe. All constraints hampering her freedom of action in her daily setting instantly fell away.
} 
step into cyberspace leaves footprints that together form individual patterns, ready to be hoovered up by commercial interests and reconfigured into targets for advertising strategies. Such data-harvesting is now the main financial engine that drives the social media sector of the Internet, including Facebook, Instagram, Amazon, and Google, turning each individual user from a free agent into a commercial cypher, intended to generate profit. Alternatively, data harvesting can be used not to group people into potential consumers, but into audiences for political messages. The focus then shifts from the profit motive to interests in political manipulation, even to what has been called the weaponization of political messages, or the demonization of political opponents. The approach in this case, as pioneered by firms like Cambridge Analytica in Britain, ${ }^{21}$ may give rise to fears among the general public that corporate interests are now able to pry on our individual lives and minds. Such fears are the latest installment of Orwellian fears of "Big Brother watching us." 22

They also may be exaggerated. Profiles of individual Internet users, such as current techniques of data analysis are able to render, cannot get much beyond the stage of clumsy hominoids drawn by a child. As the sobering voice of Masha Gessen reminds us, "We cringed at the characterization of the Russian online influence campaign as 'sophisticated' and 'vast': Russian reporting on the matter - the best available - convincingly portrayed the troll operation as small-time and ridiculous. It was, it seems, fraudulent in every way imaginable: it perpetrated fraud on American social networks, creating fake accounts and events and spreading falsehoods, but it was also fraudulent in its relationship to whoever was funding it, because surely crudely designed pictures depicting Hillary Clinton as Satan could not deliver anyone's money's worth." ${ }^{23}$ During the Cold War, Jimmy Carter reminded Americans that "Being confident of our own future, we are now free of that inordinate fear of Communism." 24 Today, whether the reference is to overrated Russian techniques of Internet manipulation or to their equivalents in the West, Masha Gessen too takes

\footnotetext{
${ }^{21}$ The British Observer was the first to reveal, about a year ago, how Cambridge Analytica worked with a Cambridge University academic, Aleksandr Kogan, to harvest Facebook data from users, without their consent, in order to model their personalities and target them politically. The Guardian, https://www.theguardian.com/technology/2019/mar/16/facebook-freshquestions-data-harvesting-cambridge-analytica?utm term= RWRpdG9yaWFs X0d1 YXJkaWFuVG9kYX1VS19 XZW V rZGF5cy0xOTAzMTg\%3D\&utm source=esp\&utm medium=Email\&utm campaign $=$ GuardianTodayUK\&CMP $=$ GTUK_email)

${ }^{22}$ For a cool-headed analysis of these recent trends, see: Shoshana Zuboff, The Age of Surveillance Capitalism: The Fight for the Future at the New Frontier of Power (London: Blackwell, 2018)

${ }^{23}$ Masha Gessen, "The Trump-Russia Investigation and the Mafia State," The New Yorker, January 31, 2019

${ }^{24} \mathrm{https}$ ://www.nytimes.com/1981/05/28/opinion/l-back-to-inordinate-fear-ofcommunism-134409.html
}

our inordinate fears of Internet prying and spying a few necessary pegs down.

That does not alter the fact that cyberspace, or the Internet as we now refer to it, against all the high hopes of the first generation of cybernauts, has succumbed to corporate interests. And succumbed is the right word here. As if in a nightmarish Francisco Goya fantasy, corporate interests now literally sit like an incubus on the networks that users of the Internet have collectively woven together. In the early search for the proper metaphor to describe the space of the Internet, as resistant to the imperialist impulse of the corporate world, the inclination was to see the Internet as horizontal opposed to the corporate world as vertical. Variations on the theme were the contrast between the square and the tower, inspired by the Renaissance cityscapes of Italy. Or in more abstract language, the contrast was between hierarchy and network. In a recent book, Niall Ferguson ranges across history, from the Freemasons to Facebook, pursuing the idea that horizontal organizations - networks -naturally spread power in more egalitarian ways than do vertical organizations. ${ }^{25}$

A more intricate metaphor, offering a synthesis between the liberating and the subjugating potentials of the Internet, is suggested by French philosopher and public intellectual Bernard-Henri Lévy. He refers back to Jeremy Bentham's prison model of the panopticon, a model offering total surveillance of the prison inmates to their all-seeing guards. That is what, in its nightmare version, our present-day Internet may seem to offer: the total surveillance of all who enter its space. In Lévy's adaptation, though, the Internet offers the opposite as well. It allows each and every user, who is sufficiently computer-savvy, to look back at the same time as being observed. The panopticon thus turns into a two-way mirror. It is an optimistic version that, I am afraid, overrates the Internet user's power to return the gaze of the incubus, of the disembodied eye, watching us on behalf of corporate interests hidden from our view. ${ }^{26}$ Due to all its quasi-self-organizing features, Facebook is misleadingly suggestive of a network expanding horizontally, as a flat and level playing field, by dint of the collective energy generated by those already involved. In fact, Facebook is primarily a giant moneymaking tool, just a busy anthill with the ant-eater sitting atop it, overseeing the busyness before his eyes, while intent on the business before him. The apparent flatness of an organization, then, may be just that: apparent.

\footnotetext{
${ }^{25}$ Niall Ferguson, The Square and the Tower: Networks, Hierarchies and the Struggle for Global Power (London: Allen Lane, 2017)

${ }^{26}$ Bernard-Henri Lévi, "The new American empire," The Atlantic, https:// www.theatlantic.com/ideas/archive/2019/01/internet-has-turned-us-silentempire/579721/ The essay is adapted from The Empire and the Five Kings: America's Abdication and the Fate of the World, by Bernard-Henri Lévy (New York: Henry Holt and Company, 2019).
} 
Nor are networks, as opposed to hierarchies, necessarily more democratic, egalitarian, or left-wing. There are many signs of populist movements, in several national settings, reaching out for international collaboration. Their appeals are often crucially nationalist, evoking the cultural and economic threats to the nation as they originate outside the national borders. Common enemies are sought and found, and Hungarian-born philanthropist George Soros is among the favorite hate figures of a coterie of international populists, to be found from Turkey to the United States. If a new International is forming it is a paradoxical one. Soros is demonized for being "cosmopolitan" and insufficiently rooted in any national setting, in language redolent with age-old anti-Semitism. Yet it is now used for trans-national bonding purposes. Similarly, in the populist quest for larger issues transcending the nation, issues such as "white racism" and immigrant hordes invading are being tried out as common ground. ${ }^{27}$ Yet no issue has proved powerful enough so far to speak across national borders to audiences aggravated by concerns relevant only within these various borders. This is not to say that there are no powerful international donors to support individual populist leaders, like Marine Le Pen, Geert Wilders and others, to perform their pernicious anti-democratic sabo- tage within their own national borders. And that one word - anti-democracy - perhaps best describes what drives the flow of dark money behind this international wrecking expedition. If it is a new International, it is nativist, antidemocratic, and anti-cosmopolitan. That is what drives the incubus riding on our back.

Open Access This article is distributed under the terms of the Creative Commons Attribution 4.0 International License (http:// creativecommons.org/licenses/by/4.0/), which permits unrestricted use, distribution, and reproduction in any medium, provided you give appropriate credit to the original author(s) and the source, provide a link to the Creative Commons license, and indicate if changes were made.

Publisher's Note Springer Nature remains neutral with regard to jurisdictional claims in published maps and institutional affiliations.

Rob Kroes is professor emeritus and former chair of the American Studies program at the University of Amsterdam, where he taught until September 2006. He is Honorary Professor of American Studies at the University of Utrecht and is a past president of the European Association for American Studies (EAAS, 1992-1996). He is the founding editor of two series published in Amsterdam: Amsterdam Monographs in American Studies and European Contributions to American Studies.

\footnotetext{
${ }^{27}$ https://www.nytimes.com/2019/01/10/us/politics/steve-king-trumpimmigration-wall.html Just one example: U.S. Congressman Steve King of Iowa, nativist and white supremacist, has forged alliances with far-right European leaders, including Marine Le Pen of France and Geert Wilders of the Netherlands, one of the most anti-Muslim politicians in Europe, who calls for closing mosques. In an interview in August with a far-right web publication in Austria, Mr. King displayed a deep familiarity with racist tracts and ideas embraced by white supremacists.
} 